\title{
Apresentação ao Número 31
}

\author{
Mariângela de Araújo* \\ Álvaro Faleiros \\ Elena Vássina
}

É com muita satisfação que apresentamos aos leitores e colaboradores da revista TradTerm este número 31. É um número especial, tendo em vista que vem marcado por uma série de mudanças.

Para iniciar, gostaríamos de oferecer nosso agradecimento muito especial à Profa. Dra. Lineide do Lago Salvador Mosca, que, desde 2005, atuou como presidente da Comissão Editorial da TradTerm e garantiu de forma exímia a qualidade da revista. Nós, da nova comissão, pretendemos continuar executando um trabalho tão bom quanto aquele desenvolvido pela Profa. Lineide.

Continuando, ressaltamos que este número foi o primeiro a apresentar a publicação em fluxo contínuo, o que, depois dos ajustes necessários, favoreceu a rápida disponibilização dos artigos, contribuindo com uma agilidade maior aos autores e aos leitores da revista, que não precisaram aguardar o fechamento do número para ter acesso aos textos. Esperamos que os próximos números sejam de publicação ainda mais ágil, de modo que possamos publicar mais artigos em um mesmo ano. Para isso, continuamos contando com a submissão de novos trabalhos.

A TradTerm 31 conta, em sua grade, com sete artigos, uma entrevista e uma resenha. Todos esses textos estão relacionados à tradução em diferentes aspectos e podemos observar algumas aproximações em suas abordagens. Em três artigos, observamos as consequências do processo tradutório quando de sua realização para diferentes gêneros e suportes. Dois artigos demonstram a interferência da variação linguística na elaboração das traduções. A resenha e a entrevista tratam da tradução de canções.

Seguindo a ordem de publicação e de paginação, o primeiro artigo, de Adriana Conceição e Christiano Santana, denominado "Os efeitos de sentido produzidos na legendagem e dublagem: o sujeito-tradutor e o processo tradutório" traz o levantamento e a análise das traduções elaboradas para o filme de animação A Nova Onda do Imperador, comparando as escolhas feitas

\footnotetext{
* Docente do Departamento de Letras Clássicas e Vernáculas da Faculdade de Filosofia, Letras e Ciências Humanas da USP.

${ }^{* *}$ Docente do Departamento de Letras Modernas da Faculdade de Filosofia, Letras e Ciências Humanas da USP

*** Docente do Departamento de Letras Orientais da Faculdade de Filosofia, Letras e Ciências Humanas da USP
}

TradTerm, São Paulo, v.31, dezembro/2018, p. 1-3

www.revistas.usp.br/tradterm 
nos processos de legendagem e dublagem, e demostrando como as diferentes escolhas levam a diversificadas construções de sentido nos textos traduzidos, de modo a evidenciar o posicionamento do sujeito-tradutor frente ao processo tradutório.

No segundo artigo, intitulado "A tradução intersemiótica de Hamlet para os quadrinhos: o solilóquio 'Ser ou não ser'”, Geisy Adriano e Leila Darin, utilizando-se do conceito de tradução intersemiótica, analisam a transposição de um trecho da peça de teatro Hamlet, de Willian Shakespeare, para a coleção Mangá Shakespeare, originalmente elaborada pela editora inglesa SelfMadeHero e disponibilizada em português brasileiro pela Galera Record.

O terceiro texto, de Elton Furlanetto, cujo título é “'Decemos nos esforçar para comunir, porque temos padrões tão diferentes de lucidar': os aspectos dialetais na linguagem de Woman on the Edge of Time, de Marge Piercy", traz uma discussão a respeito das estratégias e dificuldades para se traduzir as variantes linguísticas do inglês contemporâneo padrão presentes no livro Woman on the Edge of Time.

No quarto artigo, "O lugar da literatura juvenil distópica no polissistema literário brasileiro: o caso da trilogia 'Divergente'”, de Natália Regina da Silva e Sandra Aparecida Faria de Almeida, lemos uma reflexão sobre as opções tradutórias em uma trilogia distópica voltada ao público juvenil. As autoras destacam, em sua análise, a relevância desse tipo de literatura no Brasil e evidenciam as "destruições" pelas quais os textos passam no processo tradutório.

"Análise comparativa da obra espírita Nosso Lar e duas de suas versões em língua inglesa", o quinto artigo deste número, escrito por Ana Luiza da Silveira e Patrícia Viana Belam, diferentemente dos artigos anteriores que tinham como língua de partida o inglês, aborda duas traduções do livro Nosso Lar, escrito no Brasil, para o inglês. São analisadas, no artigo, as traduções para termos específicos do espiritismo e notas de rodapé.

No sexto artigo, denominado "A variação linguística em traduções de alta literatura e de best-sellers de ficção popular", de Lauro Maia Amorim, é analisada a existência ou não de diferenças na seleção de marcas de oralidade em traduções de obras do cânone literário e de obras de entretenimento. Para isso, foram utilizados os livros Indignação, de Philip Roth, e O Manipulador, de John Grisham, e, com o uso do software AntConc, foram analisadas e comparadas as marcas de oralidade fonéticas e morfossintáticas escolhidas na tradução das obras para o português.

O último artigo, "Chaplin e a tradução intersemiótica: uma reflexão sobre "Em Busca do Ouro", elaborado por Diogo Rossi Ambiel Facini, traz uma análise de duas versões do filme "Em Busca do Ouro", de Charles Chaplin, com base no conceito de tradução intersemiótica. Na primeira versão do filme não há falas; na segunda, as falas são inseridas, além de recursos sonoros, e a montagem é alterada. No artigo, o autor defende que Chaplin tenha atuado como um tradutor na versão de uma montagem para outra.

Encerrando este número temos uma resenha e uma entrevista, ambas tratam das traduções de canções. A resenha, apresentada por Heloísa Cintrão, refere- 
se ao livro Translating Song, de Peter Low, obra destinada a orientar tradutores de canções. A entrevista com Bïa Krieger, cantora e compositora brasileira, é realizada por Raíssa Conde, que centra suas perguntas no trabalho da cantora com as versões para o francês das canções de Chico Buarque.

Finalizamos esta apresentação agradecendo aos autores que nos confiaram os seus textos e aos pareceristas deste número. Esperamos poder contar com suas valiosas contribuições em outras oportunidades. Agradecemos ainda a Luiza Lotufo e a Sandra Albuquerque, que nos auxiliaram nesta publicação.

Desejamos uma prazerosa leitura a todos! 